\title{
PENGGUNAN MEDIA KARTU KATA BERGAMBAR DALAM MENINGKATKAN KOSAKATA SISWA DOWN SYNDROME
}

\section{THE USE OF PICTURE WORD CARD MEDIA TO IMPROVE DOWN SYNDROME STUDENT'S VOCABULARY}

\author{
S Rahayu' ${ }^{1 a}$, Rasmitadila1, dan H Makarim¹ \\ 1 Universitas Djuanda Bogor, Indonesia \\ a Korespondensi: Siti Rahayu, Email: siti.rahayu@unida.ac.id \\ (Diterima: 09-07-2018; Ditelaah: 10-07-2018; Disetujui: 11-08-2018)
}

\begin{abstract}
Mastery of vocabulary is one of the main requirements that determine the success of individuals to skilled speak. The more rich the vocabulary of the individual the greater the likelihood of individuals to skill in the language including students down syndrome who still have a little vocabulary. This case study research aims to increase the vocabulary of grade IV down syndrome student through the method of pictorial word cards. The subjects of the study were down syndrome student, which amounted to one person of grade IV SLB-C Dharma Wanita Kota Bogor. Data were collected through observation, interview and documentation. The results obtained after using the pictorial word card at the beginning of the meeting until the end of the meeting there is an increase in vocabulary. The conclusion from this research that through learning by using word card of pictorial can increase vocabulary of down syndrome students.
\end{abstract}

Keywords: down syndrome student, pictorial word card media, vocabulary.

\begin{abstract}
ABSTRAK
Penguasaan kosakata merupakan salah satu syarat utama yang menentukan keberhasilan individu untuk terampil berbahasa. Semakin kaya kosakata individu semakin besar kemungkinan individu untuk terampil berbahasa termasuk siswa down syndrome yang masih memiliki kosa kata yang sedikit. Penelitian studi kasus ini bertujuan untuk meningkatkan kosakata siswa down syndrome kelas IV melalui metode kartu kata bergambar. Subyek penelitian adalah siswa down syndrome yang berjumlah satu orang kelas IV SLB-C Dharma Wanita Kota Bogor. Data dikumpulkan melalui observasi, wawancara dan dokumentasi. Hasil yang diperoleh setelah menggunakan media kartu kata bergambar pada awal pertemuan sampai akhir pertemuan terdapat peningkatan kosakata. Kesimpulan dari penelitian ini bahwa melalui pembelajaran dengan menggunakan media kartu kata bergambar dapat meingkatkan kosakata siswa down syndrome.

Kata kunci: kosakata, media kartu kata bergambar, siswa down syndrome.

Rahayu, S., Rasmitadila, \& Makarim, H. (2018). Penggunan Media Kartu Kata Bergambar dalam Meningkatkan Kosakata Siswa Down syndrome. Didaktika Tauhidi: Jurnal Pendidikan Guru Sekolah Dasar, 5(2): 94-105.
\end{abstract}




\section{PENDAHULUAN}

Bahasa merupakan alat untuk berkomunikasi, dalam kehidupan seharihari manusia bersosialisasi dengan menggunakan bahasa baik bahasa lisan, tulisan dan bahasa isyarat. Seseorang yang terampil berbahasa yaitu seseorang yang dalam kosakata sangat baik dan benar. Kosakata merupakan hal yang penting dalam berbahasa. Kosakata merupakan pembendaharaan kata yang terdapat dalam suatu bahasa. Kualitas keterampilan berbahasa individu bergantung pada kuantitas serta kualitas kemampuan kosakata yang dimilikinya, semakin kaya kemampuan penguasaan kosakatanya maka semakin terampil dalam berbahasanya. Penguasaan kosakata merupakan salah satu syarat utama yang menentukan keberhasilan individu untuk terampil berbahasa semakin kaya kosakata individu semakin besar kemungkinan individu untuk terampil berbahasa. Penguasaan kosakata anak berawal dari kosakata umum kemudian kosakata khusus. Untuk menguasai kosakata, anak harus mampu melafalkan kata dan menyebutkan makna dari kata tersebut, sehingga dapat menyusun kata dan menyebutkan makna dari kata tersebut.

Bahasa digunakan setiap orang termasuk siswa berkebutuhan khusus, umumnya siswa berkebutuhan khusus mengalami hambatan dalam penggunaan bahasa seperti siswa down syndrome. Down syndrome merupakan kelainan kromosom dengan terbentuknya kromosom 21. Kromosom ini terbentuk akibat kegagalan sepasang kromosom yang saling memisahkan diri saat terjadi pembelahan.

Ciri khas pada siswa down syndrome selain tingkat kecerdasan yang rendah yaitu bagian fisik, khususnya alat ucap yang kurang sempurna, baik secara langsung maupun tidak langsung yang dapat mempengaruhi proses berbahasa siswa down syndrome, untuk bercakap-cakap dengan anak down syndrome itu tidak mudah karena siswa down syndrome kurang memperhatikan apa yang ditanyakan oleh guru.Siswa down syndrome merupakan anak yang mempunyai kelainan kromosom dan down syndrome merupakan salah satu bagian dari anak tunagrahita.

Pengajaran siswa down syndrome memerlukan bantuan media pembelajaran yang tepat agar anak dapat berusaha meningkatkan kreatifitas sehingga kemampuan penggunaan kosakata dapat ditingkatkan sesuai dengan kondisi anak (Rasmitadila \& Goldstein, 2017).

Agar terciptanya kegiatan belajar mengajar yang ramah dan menyenangkan serta dapat meningkatkan kosakata siswa down syndrome maka guru dalam menyampaikan materi menggunakan beberapa media seperti merangkai kartu kata bergambar yang akan digunakan oleh peneliti.

Terdapat beberapa jenis kartu kata yang digunakan sebagai alat peraga dalam membantu anak untuk meningkatkan kosakata seperti kartu kata bergambar. Gambar merupakan salah satu media visual yang konkret atau nyata. Media ini sudah dikenal di dalam setiap kegiatan pembelajaran, media gambar memberikan gambaran tentang maksud bacaan yang ada di dalamnya (Rasmitadila, Zulela \& Boeriswati, 2017). Melalui gambar, guru dapat menertejemahkan ide-ide dalam bentuk yang lebih konkret untuk siswa down syndrome. Dalam media gambar memperlancar pencapaian untuk memahami dan mengingat kata-kata yang 
ada pada gambar, media pembelajaran visual memberikan konteks untuk memahami teks, membantu siswa yang lemah dalam membaca untuk meningkatkan kosakata.

Berdasarkan studi pendahuluan yang peneliti lakukan pada siswa down syndrome di kelas IV SLB Dharma Wanita Kota Bogor yang dilakukan pada tanggal 25 Januari 2018, yaitu siswa down syndrome berjumlah 1 orang dengan berjenis kelamin laki-laki. Dalam kemampuan bahasanya yang masih dikatakan lemah dan untuk penggunaan kosakata belum lancar. Dalam proses pembelajaran siswa down syndrome berbeda dengan teman-temannya dikelas, guru memberikan konsep-konsep dasar kepada siswa down syndrome ini, seperti memberikan konsep angka 1-5 dan huruf abjad. Kemampuan siswa down syndrome dalam berkomunikasi baik dengan gurunya maupun teman-temannya tidak begitu bagus. Kadang apa yang dikatakan oleh guru kepada siswa down syndrome ini hanya diam saja karena tidak memahami apa yang dikatakan oleh gurunya.

\section{MATERI DAN METODE}

\section{Jenis Penelitian}

Metode penelitian yang digunakan yaitu kualitatif jenis pendekatan studi kasus. Instrumen yang digunakan adalah: (1) wawancara kepada guru kelas IV. (2) observasi berlangsungnya pembelajaran. (3) dokumentasi yang mendalam mengenai subfokus penelitian untuk mendapatkan hasil yang valid.

\section{Waktu dan Tempat Penelitian}

Tempat penelitian dilakukan di Sekolah Luar Biasa (SLB) Dharma Wanita Kota
Bogor yang beralamat di jalan Malabar Ujung No.2 Kota Bogor, kelurahan Tegallega, kecamatan Bogor Tengah.

Waktu penelitian dilakukan pada bulan Januari 2018 sampai dengan bulan Mei 2018 sejak melakukan observasi awal, penulisan proposal sampai pelaporan laporan penelitian.

\section{Subjek Penelitian}

Target atau subyek penelitian yang terlibat dalam penilitian ini terdiri dari 2 orang yaitu siswa down syndrome dan guru kelas IV.

\section{Prosedur Penelitian}

Penelitian ini menggunakan pendekatan kualitatif. Penelitian kualitatif adalah penelitian yang bermaksud untuk memahami fenomena tentang apa yang dialami oleh subjek penelitian.

Adapun jenis penelitian yang digunakan yaitu studi kasus. Studi kasus merupakan studi tentang kasus atau unit analisis tertentu. Metode studi kasus merupakan salah satu jenis penelitian dengan melakukan eksplorasi secara mendalam terhadap program, kejadian, proses, aktivitas, terhadap sesuatu. Studi kasus terkait oleh waktu dan aktifitas peneliti melakukan pengumpulan data secara mendetail dengan menggunakan berbagai prosedur pengumpulan data dan dalam waktu yang berkesinambungan.

Tujuan studi kasus ini adalah untuk memperoleh deskripsi yang utuh dan mendalam dari sebuah entitas. Data yang akan dideskripsikan pada penelitian ini yaitu media kartu kata bergambar dalam meningkatkan perbendaharaan kata anak down syndrome kelas IV di Sekolah Luar Biasa (SLB) Dharma Wanita Kota Bogor. 


\section{Data, Instrumen, dan Teknik}

\section{Data}

Jenis data adalah hasil pencatatan penelitian baik yang berupa fakta atau pun angka yang dijadikan bahan untuk menyusun informasi. Dalam hal ini jenis penelitian ini adalah jenis data kulitatif, penelitian kualitatif merupakan penelitian yang jenis datanya bersifat non angka.Data yang akan dihimpun oleh peneliti yaitu mengenai kosakata siswa down syndrome dengan menggunakan media kartu kata bergambar dalam proses pembelajaran.

\section{Instrumen}

Instrumen yang akan digunakan dalam penelitian ini adalah daftar wawancara dan lembar observasi catatan lapangan yang telah dibuat kisi-kisi instumen wawancara dan kisi-kisi instrumen lembar observasi.

\section{Teknik}

Tujuan utama dari suatu penelitian adalah mendapatkan data. Oleh karena itu teknik pengumpulan data merupakan langkah yang strategis dalam proses penelitian sebagai penghimpun data yang akan dideskripsikan pada penelitian.Teknik pengumpulan data dalam penelitian ini yaitu, observasi non partisipankepada guru kelas IV dansiswa down syndrome, wawancara struktur dan tidak strukturkepada guru kelas IV, studi dokumentasikepalasekolah, guru kelas IV, siswa down syndrome, dan center SLB-C Dharma Wanita Kota Bogor.

\section{Teknik Pengumpulan Data}

Pengumpulan data dalam penelitian ini menggunakan wawancara struktur dan tidak struktur, observasi non partisipan dan studi dokumentasi.

\section{Teknik Analisis Data}

Analisis data dalam penelitian kualitatif dilakukan pada saat pengumpulan data berlangsung, dan setelah selesai pengumpulan data dalam periode tertentu. Analisis data yang digunakan dalam penelitian ini yaitu model analisis Miles dan Huberman. Aktifitas dalam analisis dilakukan secara interaktif dan berlangsung secara terus menerus sampai tuntas sehingga data yang dikumpulkan dirasa cukup. Aktivitas dalam analisis data yaitu tahap reduksi data, tahap penyajian data, dan tahap penarikan kesimpulan, seperti gambar 1 .

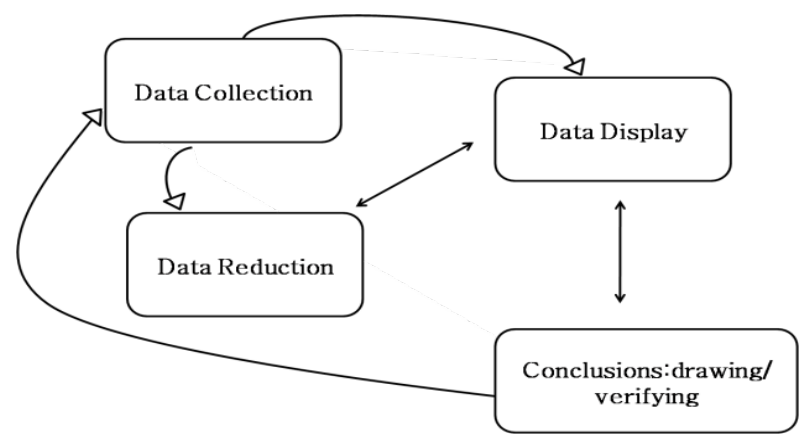

Gambar 1 Kompenen pada analisis data (interactive model)

Teknik pemeriksaan data keabsahan data dilakukan melalui triangulasi teknik yaitu observasi (guru kelas IV, dan siswa down syndrome), wawancara (guru kelas IV), dan dokumentasi.

\section{HASIL DAN PEMBAHASAN}

\section{Hasil}

Hasil temuan penelitian berdasarkan temuan dari observasi dan wawancara guru kelas IV sesuai dengan subfokus penelitian yaitu:

1. Proses penggunan media kartu kata bergambar dalam meningkatkan kosakata siswa down syndrome terdapat empat tahapan, yaitu: 
a. Menunjukan gambar

Guru menunjukan media kartu kata bergambar kepada siswa down syndrome guna menarik perhatian siswa down syndrome dan untuk mendapatkan motivasi siswa down syndrome dalam belajar, kegiatan ini terlihat pada hasil observasi catatan lapangan berikut ini.

Guru menunjukkan media kartu kata bergambar kepada siswa ds.

Siswa DS memperhatikan media kartu kata bergambar yang ditunjukkan guru.

Bu eneng: "nah (sambil memegang media kartu kata bergambar) ini apa kaka?Siswa ds: "aa (sambil menunjuk ke gambar)".

Guru menunjukan kartu kata bergambar yang sesuai dengan materi sekaligus untuk meningkatkan kosakata siswa down syndrome sebagai tahap awal pada tahap menunjukan. Pada saat guru menunjukan media kartu kata bergambar pengalihan siswa down syndrome ke media kartu kata bergambar tertuju ke media kartu kata bergambar, dan siswa down syndrome tertarik melihat ke media kartu kata bergambar.

\section{b. Mengucapkan}

Guru mengucapkan kata dengan cara mengeja huruf kata sesuai dengan kemampuan siswa down syndrome, lalu siswa down syndrome mengikuti guru. Kata yang diberikan yaitu kata dasar dengan 2-4 suku kata. Tahap mengucapkan dilakukan berulang-ulang sampai siswa down syndrome mengucapkannya jelas. Tahap mengucapkan ini guru mengucapkan kata dan siswa down syndrome mengikuti guru cara pengucapan dilakukan secara berulang-ulang sampai siswa down syndrome mengucapkan kata dengan jelas, kegiatan ini terlihat pada hasil observasi catatan lapangan berikut ini:
Guru mengucapkan kata dengan cara mengeja kata dan dilakukan secara berulang-ulang. Siswa mengucapkan kata dan mengikuti ucapan kata guru dengan berulang-ulang.

Bu eneng :"tutup (sambil menutup media kartu kata bergambar) NYA PU

Siswa ds: "PU"

Bu eneng: "NYA PU ini gambarnya ini sapunya"

Siswa ds: "PU (sambil menunjuk nunjuk gambar)"

Bu Eneng: "nyaa puuu"

Siswa down syndrome: "puu"

Pengucapan dilakukan secara berulangulang, cara guru mengucapkan kata yang ada di media kartu kata bergambar kepada siswa down syndrome yaitu dengan cara mengeja satu persatu huruf dan siswa down syndrome mengikuti sampai siswa down syndrome mengucapkannya dengan benar dan jelas.

c. Menulis

Siswa menulis kata untuk mempermudah siswa mengetahui setiap huruf kata yang ada dimedia kartu kata bergambar, cara menulis siswa dwon syndrome dengan cara menebalkan dan menyambung titik-titik pada huruf-huruf yang ada di media kartu kata bergambar, kegiatan ini terlihat pada hasil observasi catatan lapangan berikut ini:

Guru memberikan tulisan kata sesuai digambar

Siswa menulis kata dengan menebalkan titiktitik.

Bu eneng: "kaka nulisnya jangan besar-besar yah sesuaikan dengan titik-titiknya kaka pelan-pelan ajah jangan ditekan terus lagi huruf A jangan terlalu ish yah kaka jangan terlalu ditekan yah kaka pelan-pelan yah ini stop. ini mah hurufnya kekecilan garis dulu gari siswa ds : "udah bu" bu eneng: "sedikit lagi, sedikit lagi, yukayo dong kebwah, pelan lagibulet-bulet иии siswa ds : udah" 
Tahap menulis ini terdapat kecenderungan siswa lebih termotivasi untuk melakukan menulis struktur kata. Siswa merasa senang dengan menggunakan media pembelajaran yang berupa gambar karena dengan gambar-gambar yang menarik dan huruf-huruf yang berwarnawarni sehingga siswa down syndrome perhatiannya dapat terpusat pada pelajaran.

\section{d. Memahami}

Pemahaman siswa down syndrome dilakukan dengan mengikuti perintah guru seperti menyuruh siswa down syndrome melakukan cara mencuci tangan, menyapu, piket, membaca danseterusnyaseperti pada media kartu kata bergambar. Peningkatan kosakata siswa down syndrome terlihat dari siswa ds memahami kata yang diucapkan guru. Tahap ini guru meminta siswa menyebutkan kata dan melakukan atau mempraktekan sesuai dengan kata tersebut guna untuk memahami kata yang diucapkannya. Kegiatan ini terlihat dari hasil observasi catatan lapangan, berikut ini:

Bu eneng: "sapu mana sapu"

Siswa ds : "menunjuk ke sapu"

Guru melakukan pemahaman kata kepada siswa down syndrome dengan cara melakukan perintah dan mempraktekannya sesuai kata yang ada digambar seperti kata nyapu siswa down syndrome mempraktekan menyapu. Selain temuan data melalui hasil observasi, peneliti melakukan pegumpulan data melalui wawancara dengan guru kelas IV dan temuan data yang diperoleh melalui wawancara kepada GK, yaitu:

Tabel 1 Hasil wawancara guru kelas IV SLB-C Dharma Wanita

No Hasil Wawancara Guru Kelas IV

1. Peneliti: Bagaimana langkah-langkah penggunaan media kartu kata bergambar yang biasa ibu berikan pada siswa ds?

GK : contoh ini misalnya pkn atau bahasa indonesia ehh IPA deh kaya contoh kemaren IPA tuh IPA kan tentang mata nih dikasih huruf M A T A tuh yang terus anak suruh nyebutin satu-satu kaya nya ayu pernah liat deh dibukunya yang aku tulis M A T A terus dia suruh sebutin kan hurufnya satu-satu nah baru dia suruh mengeja M A= MA lebih kemengikuti yah kan anak yang lainnya kan memang diajarkan untuk mengeja $M A=$ MA, T A= TA kalau Ikhsan lebih mengikuti $M=M, A=A$ nanti MA gitu kalau untuk Ikhsan, seperti itu kita kasih lihat hurufnya suruh ngikutin menyebutkan terus kita bantu eja $\mathrm{M}$ $\mathrm{A}=\mathrm{MA}$ nya dia mampu mengucapkan ulang gitu ajah sihh kalau untuk media kartu bergambar (W.GKPMKB.16-04-18)

2. Peneliti: apakah media kartu kata bergambar cocok digunakan siswa down syndrome:

GK: media kartu kata bergambar cocok digunakan siswa ds karena memang siswa ds memerlukan media, media yang berupa visual seperti media kartu kata bergambar. Sistem pembelajaran visual yang dilakukan guru kepada siswa ds untuk memudahkan siswa ds mencerna materi karena siswa ds rata-rata IQ nya itu sekitar 30 an, pembelajaran siswa ds harus ada stimulasi yang real yang kongkrit atau nyata, selain itu media kartu kata bergambar juga dapat menarik perhatian siswa ds dan mempermudah guru juga dalam menyampaikan materi ajar kepada siswa ds dengan menggunakan media kartu kata bergambar. 
Berdasarkan hasil wawancara guru kelas (GK) mengenai proses penggunaan media kartu kata bergambar yang dilakukannya selama proses pembelajaran kepada siswa down syndrome, yaitu:

(1) menurut GK proses penggunaan media kartu kata bergambar yaitu yang pertama menunjukan gambar misalnya gambar mata dan huruf M A T A, kedua menyebutkan huruf satu persatu seperti $\mathrm{M}=\mathrm{M}, \mathrm{A}=\mathrm{A}$ baru di satukan jadi $\mathrm{M} \mathrm{A}=\mathrm{MA}$ dan seterusnya, setelah itu siswa mengikuti guru untuk mengucapkan huruf secara berulang-ulang;

(2) menurut GK media kartu kata bergambar cocok digunakan siswa ds karena memang siswa ds memerlukan media, media yang berupa visual seperti media kartu kata bergambar. Sistem pembelajaran visual yang dilakukan guru kepada siswa ds untuk memudahkan siswa ds mencerna materi karena siswa ds rata-rata IQ nya itu sekitar 30 an, pembelajaran siswa ds harus ada stimulasi yang real yang kongkrit atau nyata, selain itu media kartu kata bergambar juga dapat menarik perhatian siswa ds dan mempermudah GK menyampaikan materi ajar kepada siswa ds dengan menggunakan media kartu kata bergambar.

Pada kegiatan belajar mengajar cara guru mengajar dikelas guru mengajari siswa tunagrahita lainnya terlebih dahulu setelah itu mengajari siswa down syndrome. Pada kegiatan belajar mengajar dengan siswa down syndrome guru menjelaskan materi yang akan dipelajari dan menjelaskan materi. Untuk siswa down syndrome materinya lebih disederhanakan oleh guru sesuai dengan kemampuan siswa down syndrome dan mengaitkannya dengan media kartu kata bergambar.

2. Peningkatan kosakata setelah menggunakan media kartu kata bergambar.

Peningkatan kosakata siswa down syndrome terlihat dari keterampilan bahasa yang diucapkannya, dengan dibantu oleh media kartu kata bergambar terlihat adanya peningkatan kosakata yang dimiliki siswa down syndrome, yaitu:

a. Siswa mampu melafalkan kata

Pelafalan kata siswa down syndrome sudah bisa melafalkan kata akan tetapi pengucapan siswa down syndrome terbatas kata yang diucapkan siswa down syndrome hanya kata ujungnya saja. Pelafalan kata down syndrome terbatas untuk kata yang 2 suku kata dengan huruf lebih dari 4 hanya diujungnya saja yang dia ucapkan seperti kata SAMPAH hanya yang diucapkan PAHnya saja, untuk kata yang berjumlah kurang dari 4 huruf siswa down syndrome memampu mengucapkan nya seperti ibu, ini, itu dsb nya.

b. Siswa mampu menyebutkan makna dari kata.

Penggunaan media kartu kata bergambar dapat mempermudah siswa down syndrome untuk memahami kata, dengan adanya gambar siswa down syndome mengetahui dan melihat secara visual dapat dengan mudah untuk memahami kata, siswa down syndrome mampu menyebutkan dengan mempraktekan dan mengikuti perintah guru sesuai kata yang terdapat di media kartu kata bergambar. Selain itu hasil wawancara GK terdapat pada Tabel 2. 
Tabel 2 Hasil wawancara GK mengenai peningkatan kosakata siswa down syndrome setelah menggunakan media kartu kata bergambar

\begin{tabular}{ll}
\hline No & \multicolumn{1}{c}{ Hasil Wawancara Guru Kelas IV } \\
\hline 1. & Peneliti: apakah kosakata siswa ds sudah banyak? \\
GK: kosakata siswa ds sudah banyak seperti kata mamah, ibu, pergi, makan, minum, ini, \\
itu, tulis, iyah, gini, gitu, piket, sapu, pel, hapus, pulang, sampah, cuci tangan, nyapu, \\
buang. Walaupun ada beberapa kata yang diucapkannya atau artikulasinya tidak begitu \\
jelas dan mengucapkannya hanya ujungnya saja untuk kata-kata yang berjumlah 2 suku \\
kata. Seperti kata SAM PAH hanya diucapkan PAH. \\
\hline Peneliti: Apakah ada peningkatan dari media kartu kata bergambar kepada kosakata \\
siswa ds? \\
GK: ada peningkatannya dengan menggunakan media pembelajaran visual seperti \\
media kartu kata bergambar siswa ds ada peningkatan dalam kosakatanya dan \\
mempermudah siswa ds untuk mengingat kata dan huruf-huruf yang ada di media kartu \\
kata bergambar. Peningkatan kosakata siswa ds dapat dilihat melalui observasi GK. \\
Sebelumnya siswa ds hanya bisa mengucapkan huruf vokal dan tidak begitu banyak \\
bicara setelah menggunakan media kartu kata bergambar kosakata siswa ds mampu \\
mengetahui kata SAMPAH, NYAPU, BUANG, CUCI TANGAN, IBU, AYAH, ADIK dan \\
anggota tubuh seperti MATA, HIDUNG, dan PIPI.
\end{tabular}

3. Peneliti: Bagaimana cara ibu melihat dan menilai peningkatan siswa ds dengan menggunakan media kartu bergambar? Apakah ada penilaiannya?

GK: ada, ada penilaiannya jadi observasi kalau ditematik itu kan setiap temanya ada evaluasinya nah evaluasi itu tentang apa yang kita berikan saya suka langsung mengevaluasi dibuku anak-anak langsung ditulis disitu mampu dan tidaknya jadi bukan penilaian berupa angka kalau di SLB mah mampu dan tidak mampunya atau misalnya mampu tapi mampu dengan bantuan maksudnya mampu dengan bantuan teh kaya misalnya antara $b$ dan d Ikhsan itu masih kebalik atau masih belum paham kan saya ngjelasinnya gini Ikhsan kalau huruf b perutnya itu kedepan kalau d itu perutnya ke belakang nah itu kan misalnya pemahamannya gitu nah itu yang kadang sulit mah jadi kalau misalnya kaya gitu mampu dengan bantuan atau mampu dengan bimbingan dengan arahan kadang ada ada penjelasannya gitu yu anak-anak tuh dikasih mampu tapi mampunya penjelasannya apa gitu atau dia tidak mampu, tidak mampunya dimana gitu jadi pakai deskripsilah.

Peningkatan kosakata siswa down syndrome setelah menggunakan media kartu kata bergambar terdapat adanya peningkatan kosakata siswa down syndrome terlihat pada tabel 3 .

Penggunaan media kartu kata bergambar dapat mempermudah siswa down syndrome untuk memahami kata, dengan adanya gambar siswa down syndome mengetahui dan melihat secara visual dapat dengan mudah untuk memahami kata, siswa down syndrome mampu menyebutkan dengan mempraktekan dan mengikuti perintah guru sesuai kata yang terdapat dimedia kartu kata bergambar. Terdapat adanya 
peningkatan siswa down syndrome setelah menggunakan media kartu kata bergambar.

Tabel 3 Peningkatan kosakata siswa down syndrome sebelum dan sesudah menggunakan media kartu kata bergambar

\begin{tabular}{lll}
\hline \multicolumn{1}{c}{ Sebelum } & \multicolumn{2}{c}{ Sesudah } \\
\hline Huruf vokal & Huruf abjad A-H \\
Ibu & Sampah \\
Bapak & Nyapu \\
Ini & Nulis \\
Itu & Buang & \\
& Cuci tangan & \\
& Ayah, Adik \\
& Piket Angota tubuh $\quad$ (mata, \\
& Anggota pipi) \\
\hline
\end{tabular}

Adapun Faktor-faktor yang menjadi penghambat penggunaan media kartu kata bergambar dalam meningkatkan kosakata siswa down syndrome, antara lain:

\section{a. Faktor IQ}

Faktor yang menghambat media kartu kata bergambar dalam meningkatkan kosakata siswa down syndrome yaitu kemampuan kognitif siswa down syndrome dengan IQ dibawah rata-rata, dan kemampuan pengucapan siswa down syndrome dengan artikulasi yang kadang tidak jelas diucapkannya.

Selain itu menurut GK dari hasil wawancara mengenai IQ yang dimiliki siswa down syndrome dikelas IV SLB-C Dharma Wanita yaitu sekitar 50 hal ini akibat dari kelainan kromosom, maka dari itu sistem pembelajaran yang digunakan dan diterapkan guru yaitu dengan menggunakan visual atau kongkrit dengan mengaitkan materi dengan hal-hal atau pengalaman yang nyata untuk mempermudah guru menyampaikan materi dan mempermudahkan siswa down syndrome untuk menangkap materi. Selain itu materi yang diberikan kepada siswa down syndrome lebih sederhana dari siswa lainnya seperti contohnya tema uang, materi uang yang diberikan kepada siswa lainnya seperti uang 500, 1.000, 2.000, 5.000, dan 10.000 sedangkan untuk siswa down syndrome yaitu 500, 1.000 dan 2.000. Seperti yang dikatakan GK dalam wawancara, dibawah ini:

Peneliti: "bagaimana persiapan ibu dalam pembelajaran?

GK: "kalau saya sihh disesuaikan dengan tema yang ada dibuku tematik kalau misalnya kebeneran temanya uang berarti anak-anak dipersiapkan untuk bawa uang sesuai dengan perintah misalnya kaya kemaren uang lima ratus, seribu, dua ribu, lima ribu, sepuluh ribu suruh dibawa kalau ikhsan tetep disamakan dibawa cuman untuk prakteknya dia hanya sekedar kita sebutkan kadang uang itu sebenarnya udah terlalu tinggi yah jadi untuk ikhsan mah bawa mah tetap disamakan dibawa tapi untuk pemberian materinya paling lima ratus sama seribu gitu dua jadi gini kalau untuk tunagrahita lain mah misalnya konsep uang kita kasih lima item dari mulai lima ratus, seribu, dua ribu, lima ribu, sepuluh ribu nah tapi untuk ikhsan mah cukup dua kalau misalnya mengeja misalnya mereka mah satu kalimat ikhsan cukup misalnya buku kaya gitu hanya satu kata untuk dua kata ikhsan udah bisa tapi (kaka ga boleh bilang gitu reva jangan diajarin kaya gitu) jadi kalau misalnya dua suku kata juga mau tapi tidak akan jelas banget tetap ajah yang jelas mah satu kata terus disatu kata juga kebanyakan diejaan pertama ilang jadi sebenarnya dia tau kaya misalnya ini sampah tapi dia itu samnya ga diucapin hanya pahnya kalau misalnya sam dia ikutin sam tapi malah dia ngelanjutin sam pah gitu jadi sebenarnya tau cuman pola ini nya belum ketemu yu pola biar dia pengucapannya sepenuhnya seluruhnya tapi dia hanya meneruskan jatohnya karena memang meniru kan anak kaya gini mah jadi hanya mengucapkan akhirannya ajah, pahamnya mah iyah paham sebenarnya sihh bagusnya mah sihh dibarengin sama terapi, terapi wicara Cuma kan kembali 
lagi ke kemampuan orang tua yah kita juga dah yang namanya terapi wicara apalagi di biro-biro yang tertentu atau dirumah sakit mah lumayan harganya, harusnya mah sarannya mah kan kalau terapi wicara mah yu beda gitu cara ada buat ngeiniinnya tuh kaya sikat gigi terus ngeiniin rahangnya atau apalah kaya ada kuesioner terapi nya untuk bagian ini, kalau kita memang bukan ininya yah bukan ranahnya jadi hanya sekedar tau dan menerapkannya juga kita tidak bisa sepenuhnya nerapin paling kita neraping $N G$ ngucapin $N G$ gini $N G$ gitu dipencet hidungnya MMMM $M$ kan harus di tutup mulutnya biar MM gitu paling kita hanya bisa ngikutin segitu-gitu ajah".

Dari hasil wawancara kepada GK mengatakan bahwa untuk siswa down syndrome pembelajaran yang diberikannya disederhanakan dan cukup disingkat karena sesuai dengan kemampuannya, misalnya untuk siswa lainnya diberikan kalimat sedangkan siswa down syndrome hanya satu kata seperti kata sampah, buang, baca dan sebagainya.

b. Fisik siswa down syndrome

Fisik siswa down syndrome terlihat normal akan tetapi dari segi wajah seperti ciri-ciri siswa down syndrome lainnya seperti mempunyai paras muka yang hampir sama seperti muka orang Mongol, mempunyai jari-jari yang pendek dan mempunyai otot yang lemah.

Selain itu siswa down syndrome juga terhambat dari pengucapannya, pengucapan siswa down syndrome terbatas dan kurang jelas artikulasinya, seperti yang dikatakan GK pada wawancara bahwa pengucapan siswa down syndrome ada beberapa kata yang tidak jelas, pengucapan siswa down syndrome untuk kata yang panjang hanya diucapkan ujung kata saja seperti kata sampah yang diucapkan siswa down syndrome pah.

\section{c. Fokus Siswa down syndrome}

Siswa down syndrome kesulitan fokus dalam durasi yang lama, seperti Ikhsan menurut GK fokus Ikhsan tergantung moodnya kalau dirumahnya kurang tidur pasti dikelas dia tidur dan tidak fokus ke pelajaran kadang moodnya susah untuk diajak belajar ikhsan hanya ingin tidur. Seperti yang dikatakan GK dalam wawancara. Maka dari itu penggunaan media kartu kata bergambar dapat mengalihkan fokus siswa down syndrome, dengan cara menunjukkan media kartu kata bergambar agar tetap fokus.

\section{Pembahasan}

Pembelajaran dengan menggunakan media kartu kata bergambar mampu meningkatkan kosakata siswa down syndrome kelas IV SLB-C Dharma Wanita Kota Bogor. Peningkatan tersebut dapat dilihat dan dibuktikan dari hasil catatan lapangan observasi, wawancara guru kelas dan pengucapan siswa down syndrome. Siswa down syndrome mampu melafalkan kata dan memahami makna kata tersebut. Hal tersebut sesuai dengan teori penguasaan kosakata. Penguasaan kosakata dapat dilihat dari bagaimana siswa melafalkan kata baru dan memahami makna. Kosakata yang diberikan siswa down syndrome adalah kata dasar dan kata tunggal. Kata yang dimiliki siswa down syndrome sebelum menggunakan media kartu kata bergambar adalah kata ibu, bapak, ini, itu dan huruf vokal setelah menggunakan media kartu kata bergambar siswa down syndrome mampu melafalkan kata dan memahami makna kata yaitu kata seperti kata buang, sampah, piket, cuci tangan, anggota tubuh (mata, hidung dan pipi) dan uruf abjad (a sampai h). Kata tersebut telah dipahami oleh siswa down syndrome. 
Adapun keberhasilan tersebut dilakukan dengan langkah-langkah penggunaan media kartu kata bergambar, yaitu langkah pertama guru menunjukan media kartu kata bergambar kepada siswa down syndrome, langkah kedua mengucapkan kata secara berulang-ulang sampai siswa down syndrome jelas mengucapkan kata yang ada dimedia kartu kata bergambar, langkah ketiga menulis kata yang sesuai dengan kata yang terdapat dimedia kartu kata bergambar, langkah keempat memahami makna kata dengan mempraktekan kata yang terdapat di media kartu kata bergambar yang ditunjukkan oleh guru. Selain itu adanya beberapa faktor yang menghambat penggunaan media kartu kata bergambar seperti IQ yang dimiliki siswa down syndrome yaitu dibawah 50, maka hal tersebut mengakibatkan adanya keterlambatan dalam pembelajaran guru memberikan materi sesederhana mungkin untuk siswa down syndrome dan untuk kosakata yang diberikannya perhari hanya 3 kosakata baru, faktor lainnya yaitu fisik siswa down syndrome, siswa down syndrome memiliki fisik yang berbeda dari siswa lainnya karena kelainan kromosom yang mengakibatkan fisik siswa down syndrome berbeda salah satunya yaitu alat pengucapannya siswa down syndrome keterbatasan dalam hal pengucapan, kata yang artikulasi siswa down syndrome tidak begitu jelas seperti orang cadel dan kata yang diucapkan hanya kata yang diujung nya saja, faktor penghambat lainnya yaitu faktor fokus siswa down syndrome, fokus siswa down syndrome mudah mengalihkan maka dari itu guru harus mampu mengalihkan fokus siswa down syndrome ke pembelajaran, dengan penggunaan media kartu kata bergambar fokus siwa down syndrome teralihkan karena adanya gambar- gambar dan warna-warna yang ada dimedia kartu kata bergambar.

\section{KESIMPULAN DAN IMPLIKASI}

\section{Kesimpulan}

Berdasarkan hasil penelitian terhadap satu subyek tersebut, diperoleh data-data yang merupakan jawaban dari subfokus penelitian ini, yang mencakup penggunaan media kartu kata bergambar dalam meningkatkan kosakata siswa down syndrome, yaitu:

1. Proses penggunaan media kartu kata bergambar yaitu guru menunjukkan media kartu kata bergambar kepada siswa down syndrome, mengucapkan kata, guru mengucapkan kata dan siswa down syndrome mengikutinya, menulis kata, memahami makna kata, siswa down syndrome memahami kata yang diucapkan guru dan memahami makna kata yang terdapat di media kartu kata bergambar.

2. Adanya peningkatan kosakata siswa down syndrome dengan menggunakan media kartu kata bergambar terlihat dari:
a. Siswa down syndrome mampu melafalkan kata
b. Siswa down syndrome mampu memahami makna kata.

3. Faktor yang menghambat penggunaan media kartu kata bergambar siswa down syndrome yaitu faktor IQ yang dimiliki siswa down syndrome yaitu 50, faktor penghambat lainnya yaitu fisik akibat kromosom yang dialami siswa down syndrome fisik siswa down syndrome berbeda dengan siswa lainnya salah satunya yaitu alat ucapnya siswa down syndrome dalam mengucapkan kata 
artikulasinya tidak begitu jelas seperti orang cadel dan kata yang diucapkannya kata yang diujungnya saja, dan faktor yang menghambat penggunaan media kartu kata bergambar yang terakhir yaitu fokus siswa down syndrome yang mudah teralihkan ke yang lain.

\section{Implikasi}

Implikasi dari penelitian ini yaitu pentingnya penggunaan media kartu kata bergambar dalam meningkatkan kosaka siswa down syndrome dan dalam proses pembelajaran siswa down syndrome membutuhkan media visual seperti media kartu kata bergambar. Hasil penelitian menunjukan bahwa adanya peningkatan kosakata siswa down syndrome setelah menggunakan media kartu kata bergambar. Maka dari itu peneliti lain diharapkan penelitian ini dapat menjadi bahan acuan untuk melaksanakan penelitian berikutnya, sehingga dapat mengoptimalkan penggunaan media kartu kata bergambar dalam meningkatkan kosakata siswa down syndrome.

\section{DAFTAR PUSTAKA}

Abdurrahman, M. (2010). Pendidikan Bagi Anak Berkesulitan Belajar. Jakarta: Asdi Mahastya.

Ariani, Y. (2012). Perubahan Dan Pelepasan

Fonem Dalam Kegiatan Bercakap-Cakap

Pada Anak Down syndrome Di Sekolah Luar Biasa Cahaya Mentari Kartasura.

Smart, A. (2010). Anak Cacat Bukan Kiamat

(Meote Pembelajaran Dan Terapi Untuk Anak Berkebutuhan Khusus). Yogyakarta: Katahati.
Tarigan, H. G. (2011). Pengajaran Kosakata. Bandung: Angkasa.

Sunarsih. (2012). Upaya Meningkatkan Kemampuan Membaca Permulaan Dengan Menggunakan Pias Kata Asosiasi Gambar Pada Siswa Tunagrahita Kelas D2, C1 Semeser II SLB-ABCD Simo Boyolali Tahun pelajaran 2011/2012. Universitas sebelas maret. Surakarta

Subana. (2011). Strategi Belajar Mengajar Bahsa Indonesia. Bandung: Pustaka Setia. Noviani, E. (2014). Pengaruh Permainan Kartu Bergambar Untuk Meningkatkan Kosakata Pada Anak Autis Kelas Tk Di Sekolah Autisme Bina Anggita Yogyakarta. Universitas Negeri Yogyakarta.

Moleong, L. J. (2014). Metodologi Penelitian Kualitatif. Bandung: Remaja Rosdakarya Offset.

Rasmitadila, R., \& Goldstein, B. (2017). The Role of Special Assistant Teacher to Help Special Needs Student through Instructional Interactions in an Inclusive Classroom. International Journal of Special Education, 32, 485-506.

Rasmitadila, R., Zulela.,\& Boeriswati, E. (2017). Peers' Instructional Interactions in Inclusive Classrooms: Slow Learner Students and Typical Students. International Journal of Multidisciplinary and Current Research, 5, July/Aug, 904911.

Sugiyono. (2015). Metode Penelitian Kuantitatif, Kualitatif Dan R \& D. Bandung: Alfabeta.

Arifin, Z. (2012). Penelitian Pendidikan. Bandung: Remaja Rosdakarya.

Musfiqon. (2012). Metode Penelitian Pendidikan. Jakarta: Prestasi Pustakarya. 